\title{
Reversible brain shrinkage secondary to infant salt toxicity
}

Andrew C.H. Ho, MBBS, Sarah W.Y. Poon, MBBS, MRCPCH, DCH (HK), and Anderson C.O. Tsang, MBBS, FRCS Neurology ${ }^{\circledR}$ 2020;94:1103-1104. doi:10.1212/WNL.0000000000009651

A previously healthy 9-month-old girl was obtunded due to marked hypernatremia. She was resuscitated with IV hydration with progressive correction of sodium level. CT brain scan on admission showed marked brain shrinkage, which resolved as the sodium level was corrected (figure).

Salt toxicity is rare but potentially fatal in children and should be suspected in severe hypernatremia without significant dehydration or metabolic cause. ${ }^{1}$ Children may recover without long-term sequelae but seizure is commonly reported when hypernatremia is corrected rapidly. ${ }^{2}$ In this patient, the culprit was excessive exogenous sodium intake from inappropriate weaning food.

Figure Reversible brain shrinkage due to salt toxicity

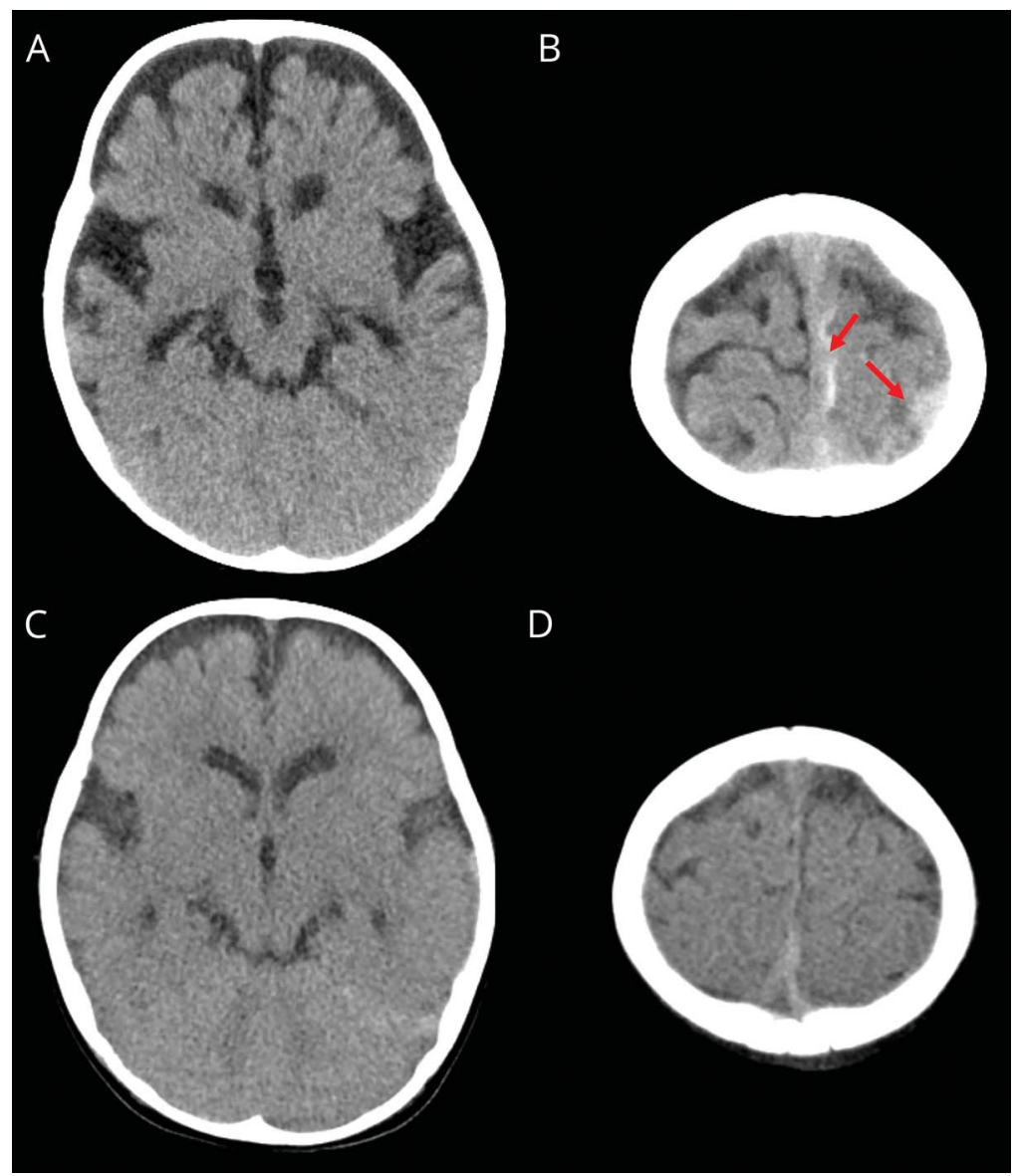

(A, B) Noncontrast CT scan with severe hypernatremia (194 mmol/L) shows cerebral parenchymal shrinkage with prominent subarachnoid space, enlarged Sylvian cistern, and acute subdural hemorrhage (arrows). (C, D) CT scan after correction of hypernatremia (155 mmol/L) shows reversed brain shrinkage with reduction in extraaxial CSF and subdural hemorrhage.

\author{
Correspondence \\ Dr. Tsang \\ acotsang@hku.hk
}




\section{Study funding}

No targeted funding reported.

\section{Disclosure}

The authors report no relevant disclosures. Go to Neurology. org/N for full disclosures.

\begin{tabular}{lll}
\hline \multicolumn{2}{l}{ Appendix Authors } & \\
\hline Name & Location & Contribution \\
\hline $\begin{array}{l}\text { Andrew C.H. Ho, } \\
\text { MBBS }\end{array}$ & $\begin{array}{l}\text { Division of Neurosurgery, } \\
\text { Department of Surgery, } \\
\text { Queen Mary Hospital, The } \\
\text { University of Hong Kong }\end{array}$ & $\begin{array}{l}\text { Data } \\
\text { interpretation and } \\
\text { drafting of } \\
\text { manuscript }\end{array}$ \\
\hline
\end{tabular}

Appendix (continued)

\begin{tabular}{lll}
\hline Name & Location & Contribution \\
\hline $\begin{array}{l}\text { Sarah W.Y. Poon, } \\
\text { MBBS, MRCPCH, } \\
\text { DCH (HK) }\end{array}$ & $\begin{array}{l}\text { Department of Paediatrics } \\
\text { and Adolescent Medicine, } \\
\text { Queen Mary Hospital, The } \\
\text { University of Hong Kong }\end{array}$ & $\begin{array}{l}\text { Data } \\
\text { interpretation and } \\
\text { drafting of } \\
\text { manuscript }\end{array}$ \\
\hline $\begin{array}{l}\text { Anderson C.O. } \\
\text { Tsang, MBBS, }\end{array}$ & $\begin{array}{l}\text { Division of Neurosurgery, } \\
\text { Department of Surgery, } \\
\text { Queen Mary Hospital, The } \\
\text { University of Hong Kong }\end{array}$ & $\begin{array}{l}\text { Study design and } \\
\text { supervision }\end{array}$ \\
& &
\end{tabular}

\section{References}

1. Paut $\mathrm{O}$, Andre N, Fabre $\mathrm{P}$, et al. The management of extreme hypernatraemia secondary to salt poisoning in an infant. Pediatr Anesth 1999;9:171-174.

2. Leung C, Chang WC, Yeh SJ. Hypernatremic dehydration due to concentrated infant formula: report of two cases. Pediatr Neonatal 2009;50:70-73. 


\section{Neurology}

\section{Reversible brain shrinkage secondary to infant salt toxicity \\ Andrew C.H. Ho, Sarah W.Y. Poon and Anderson C.O. Tsang \\ Neurology 2020;94;1103-1104 Published Online before print May 27, 2020 \\ DOI 10.1212/WNL.0000000000009651}

This information is current as of May 27, 2020

Updated Information \&
Services

References

Subspecialty Collections

Permissions \& Licensing

Reprints including high resolution figures, can be found at:

http://n.neurology.org/content/94/24/1103.full

This article cites 2 articles, 0 of which you can access for free at: http://n.neurology.org/content/94/24/1103.full\#ref-list-1

This article, along with others on similar topics, appears in the following collection(s):

All Clinical Neurology

http://n.neurology.org/cgi/collection/all_clinical_neurology

All Pediatric

http://n.neurology.org/cgi/collection/all_pediatric

Coma

http://n.neurology.org/cgi/collection/coma

Critical care

http://n.neurology.org/cgi/collection/critical_care

Information about reproducing this article in parts (figures,tables) or in its entirety can be found online at:

http://www.neurology.org/about/about_the_journal\#permissions

Information about ordering reprints can be found online:

http://n.neurology.org/subscribers/advertise

Neurology ${ }^{\circledR}$ is the official journal of the American Academy of Neurology. Published continuously since 1951, it is now a weekly with 48 issues per year. Copyright @ 2020 American Academy of Neurology. All rights reserved. Print ISSN: 0028-3878. Online ISSN: 1526-632X.

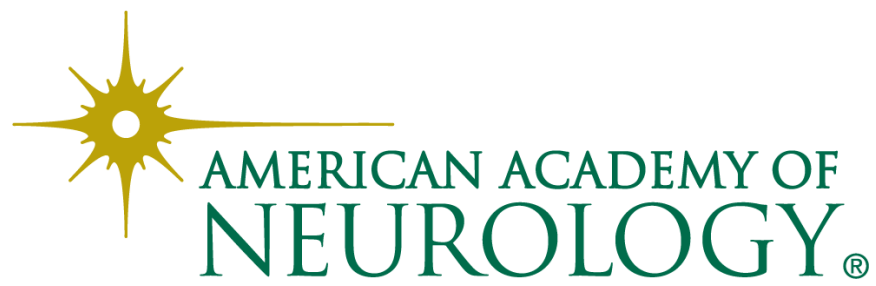

